\title{
Study of Antimicrobial activity of selected Iranian plant extracts on vancomycin resistant Staphylococcus epidermidis
}

\author{
Abachi S. ${ }^{1 *}$, Khademi F. ${ }^{2}$, Fatemi H. ${ }^{3}$, Malekzadeh F. ${ }^{4}$ \\ ${ }^{1 \& 4}$ Department of Food Science, Agriculture \& Natural Resources Research Center, Qom, Iran \\ ${ }^{2 \& 3}$ Department of Microbiology, Agriculture Research Center, Tabriz, Iran
}

\begin{abstract}
Staphylococcus epidermidis is one the common bacteria causing infections in humans. Its increasing resistance has led to growing use of antibiotic and introduction of new medicines into the market. Strains of Staphylococcus epidermidis are or becoming resistant to many antibiotics, including vancomycin. Since the resistance of the bacteria to vancomycin is increasing, it is important to replace vancomycin with alternative medicines. This study explores antibacterial effects of hydroalcoholic extracts of selected Iranian medicinal plants on clinical vancomycin-resistant strains of Staphylococcus epidermidis. Hydroalcoholic extracts of plant organs with reported experimental antimicrobial effects, Lagenaria vulgaris, Punica grantum, Allium ascalonicum, Persian Marjoram, Urtical duicia, Chicorium intybus, Rubia tinctorum, Trigonella foenum, Descurainia sophia, and Pistaca vera were examined using disk diffusion and dilution antimicrobial susceptibility tests in liquid medium to determine the minimum inhibitory concentration of 15 strains of vancomycin-resistant Staphylococcus epidermidis. The highest and lowest minimum inhibitory concentration were found for the extracts of Allium ascalonicum $\left(M^{2} C_{50} 128 \mu \mathrm{g} / \mathrm{ml}\right)$ and Lagenaria vulgaris $\left(M_{I} C_{50} 1000 \mu \mathrm{g} / \mathrm{ml}\right)$, respectively. Since a growing resistance to vancomycin is observed in Staphylococcus epidermidis, our findings may be important because of the considerable effect of Allium ascalonicum extract on isolated vancomycin-resistant Staphylococcus epidermidis. Further research is required into the clinical applications of extracts.
\end{abstract}

Keywords- Resistant Staphylococcus epidermidis; Medicinal plants

\section{Introduction}

Staphylococcus epidermidis is a significant pathogenic bacterium which causes a wide range of infections that sometimes can lead to the death of the infected person [1,2]. The increase in nosocomial infection rate at healthcare and medical institutions largely contributes to the growing economic burden for treating infections. Such infections are among the major causes of death for patients at hospitals [3-5]. Staphylococcus epidermidis cells are naturally found in the form of gram-positive, a Coagulase-negative Staphylococci(CoNS )arranged in irregular grape-like clusters on human skin and mucous membranes [6,7]. There are many species of CoNS but the most common isolate recovered from clinical specimens is $S$. epidermidis [8].CoNS isolates typically are more resistant to antimicrobial agents than $S$. aureus with the prevalence of resistance to betalactams as high as $60-70 \%$ [9]. The greatest challenge in treating infections caused by S. epidermidis is its increasing resistance to antibiotics, including vancomycin [10-12].

A new approach has developed to using medicinal plants in treating infections. Given the natural availability, limited side effects, and relatively low cost of medicinal plants, researchers are trying to identify antimicrobial activities of these plants [13-17]. The present study explores antibacterial effects of hydroalcoholic extracts from 10 plants whose antimicrobial effects on vancomycin-resistant S. epidermidishave been reported by experimental studies.

\subsection{Collection of plants}

\section{Materials And Methods}

Ten local medicinal plants with the following Ethno-botanical information were chosen for this study:1- Bottle Gourd seed(Lagenaria vulgaris), 2- Pomegranate fruit (Punica grantum), 3- Shallot bulb (Allium ascalonicum), 4- Parsnip flower (Persian marjoram), 5- Nettle leaves (Urtical duicia), 6- Chicory root (Chicorium intybus), 7- Madder root (Rubia tinctorum), 8- Fenugreek seed (Trigonella foenum), 9- Cyclops seed (Descurainia sophia), and 10- Pistachio nut green shell (Pistaca vera).Fresh parts of selected plants were identified, and collected from agriculture \& natural resources research center and two regions (VaraminPishva35.278117 N, 51.652908 E, Sorkheh Hesar National Park 35.695083 N, 51.589651 E) and analyzed in the laboratory of microbiology department .Fresh plant material was washed under running tap-water, air dried, and then homogenized to fine powder and stored in airtight bottles within dark and dry environment. 


\subsection{Extraction}

Extraction was carried out through maceration process. In this process, 50 gram of dried powder from leaves, seeds, bulbs, or fruits was put into ethanol at $70^{\circ} \mathrm{C}$, centrifuged for 72 hours at room temperature, and slowly mixed. Then common filter papers and vacuum distillation apparatus were used to concentrate and dry the extracts [18].

\subsection{Microbial strain}

Domestic strains of S. epidermidis, taken from infected dialysis subjects, infected with nosocomial infections, from Shafa Medical Care Center were identified at the microbiology laboratory using biochemical tests (catalase, coagulase, DNase, and Mannitol salt agar). In the next step, we explored the impact of vancomycin $(32 \mu \mathrm{g} / \mathrm{ml})$ on these strains, and 15 strains were identified as being resistant to this antibiotic at this concentration $[19,20]$

\subsection{Microbial sensitivity test}

Kirby-Bauer test (disk-diffusion method),was used to identify strain sensitivity to the 10 plant extracts[21]. A 0.5 McFarland standard sample was prepared for each strain in Mueller-Hinton Broth and cultured on Mueller-Hinton agar. Blank disks were immersed in $100 \mu \mathrm{g} / \mathrm{ml}$ extracts, dried, and placed on a plate with Mueller-Hinton agar at pre-determined intervals. A disk impregnated with distilled water (blank disk) together with a disk containing vancomycin (standard disk) was placed on each plate. The plates were incubated at $37^{\circ} \mathrm{C}$ for 24 hours and analyzed by measuring the diameter of inhibition zone around the extract-containing disks. For accuracy, the test was performed in duplicates for each extract and the average diameter of inhibition zone was taken into account in case of any variation in the two measurements.

\subsection{Determination of minimum inhibitory concentration (MIC)}

Sterile 96-well plates were used to determine minimum inhibitory concentration (MIC) through micro broth dilution. In this method, $75 \mu \mathrm{l}$ of a $0.5 \mathrm{McFarland}$ standard 1:1,000 suspension of the bacterium (equivalent to $1.5 \times 10^{8} \mathrm{Cfu} / \mathrm{ml}$ ) was added to a microwell containing $75 \mu \mathrm{l}$ of 2-5,000 $\mu \mathrm{g} / \mathrm{ml}$ extracts in MullerHinton Broth. Control organism suspension and the culture medium were dispensed into one row and herbal extracts with different concentrations were added to one column. The microplates were incubated for 24 hours at $37^{\circ} \mathrm{C}$.The minimum concentrations of extracts with no growth-induced turbidity were recorded as MICs $[19,20]$.

\subsection{Statistical data analysis}

The data were analyzed in SPSS ( $v=11)$ using Duncan and Touki tests as well as F test $[22,23]$.

\section{Results}

Antimicrobial effects of hydroalcoholic extracts of Lagenaria vulgaris, Punica grantum, Allium ascalonicum, Persian marjoram, Urtical duicia, Chicorium intybus, Rubia tinctorum, Trigonella foenum, Descurainia sophia, and Pistaca vera on vancomycin-resistant strains of $S$. epidermidis were examined in this study. As seen in Tables 1\&2, among the 10 extracts examined, Allium ascalonicum has the strongest antibacterial effect on all strains. MIC of Allium ascalonicum extract for three strains was $64 \mu \mathrm{g} / \mathrm{ml}$ while the maximum inhibitory concentration was observed only for one strain at $1,000 \mu \mathrm{g} / \mathrm{ml}$. Lagenaria vulgar is extract, with the largest MIC among the extract studied, and affected two strains at $256 \mu \mathrm{g} / \mathrm{ml}$ and five strains at a concentration larger than $5,000 \mu \mathrm{g} / \mathrm{ml}$. The smallest and the largest values of $\mathrm{MIC}_{50}$ were found for Allium ascalonicum extract $(128 \mu \mathrm{g} / \mathrm{ml})$ and Lagenaria vulgaris extract $(1,000 \mu \mathrm{g} / \mathrm{ml})$, respectively (Table 3). According to $\mathrm{F}$ test results, the extracts exhibited different effects on the bacteria $(\mathrm{P} \leq 0.05)$, and Touki test found the largest difference between Lagenaria vulgaris and Allium ascalonicum $(\mathrm{P} \leq 0.05)$. The smallest $\mathrm{MIC}_{90}$ was found for Allium ascalonicum extract $(512 \mu \mathrm{g} / \mathrm{ml})$ while the largest $\mathrm{MIC}_{90}$ belonged to Lagenaria vulgaris, Punica grantum, and Chicorium intybus (over $5,000 \mu \mathrm{g} / \mathrm{ml}$ ). According to Duncan test, the second-most effective extract, following Allium ascalonicum, was Persian marjoram with $\mathrm{MIC}_{90} 1,000 \mu \mathrm{g} / \mathrm{ml}$ and $\mathrm{MIC}_{50} 256 \mu \mathrm{g} / \mathrm{ml}$.

Disk diffusion results suggest stronger effects of Allium ascalonicum on the strains. The disk impregnated with Allium ascalonicum extract inhibited growth in all strains. Diameter of inhibition zone was 10 $\mathrm{mm}$ for Strain number 11 and $30 \mathrm{~mm}$ for two other strains. Persian marjoram was the next extract, following Allium ascalonicum, in terms of the of inhibition zone diameter. Persian marjoram extract created no inhibition zone only in three strains. The smallest inhibition zone $(9 \mathrm{~mm})$ was observed for one strain and the largest inhibition zone $(20 \mathrm{~mm})$ was found in another single strain. According to the same test, Lagenaria vulgaris, Punica grantum, and Trigonella foenum extracts had the smallest effect in terms of inhibition zone. Inhibition zone around the disks containing Lagenaria vulgaris, Chicorium intybus extract, and Trigonella foenum extracts were observed in 7,8 , and 9 strains, respectively. 
Table 1: Minimum concentration of extracts inhibiting the growth of selected isolates of staphylococcus epidermidis resistant to vancomycin -microgram per milliliter $(\mu \mathrm{g} / \mathrm{ml})$ -

\begin{tabular}{|c|c|c|c|c|c|c|c|c|c|c|}
\hline & $\begin{array}{l}\text { Lagenaria } \\
\text { vulgaris }\end{array}$ & $\begin{array}{c}\text { Punica } \\
\text { granatum }\end{array}$ & $\begin{array}{c}\text { Allium } \\
\text { ascalonicum }\end{array}$ & $\begin{array}{c}\text { Persian } \\
\text { marjoram }\end{array}$ & $\begin{array}{l}\text { Urtica } \\
\text { dioica }\end{array}$ & $\begin{array}{c}\text { Cichorium } \\
\text { intybus }\end{array}$ & $\begin{array}{c}\text { Rubia } \\
\text { tinctorum }\end{array}$ & $\begin{array}{l}\text { Trigonella } \\
\text { foenum }\end{array}$ & $\begin{array}{c}\text { Descurainia } \\
\text { sophia }\end{array}$ & $\begin{array}{c}\text { Pistacia } \\
\text { vera }\end{array}$ \\
\hline 1 & 1000 & $5000<$ & 64 & 64 & 128 & 1000 & 128 & 256 & 512 & 1000 \\
\hline 2 & $5000<$ & 512 & 128 & 1000 & 256 & 512 & 128 & 1000 & $5000<$ & $5000<$ \\
\hline 3 & $500<$ & 512 & 256 & 512 & 512 & 512 & 256 & 512 & 2000 & 256 \\
\hline 4 & $5000<$ & 256 & 512 & 1000 & 1000 & 256 & 256 & 1000 & 512 & 1000 \\
\hline 5 & 1000 & $5000<$ & 512 & 1000 & $5000<$ & $5000<$ & 1000 & $5000<$ & $5000<$ & $5000<$ \\
\hline 6 & 2000 & 256 & 128 & 64 & 512 & 64 & 128 & 512 & 1000 & 1000 \\
\hline 7 & 2000 & $5000<$ & 512 & $5000<$ & 1000 & 2000 & 1000 & 1000 & $5000<$ & 64 \\
\hline 8 & 256 & $5000<$ & 256 & 1000 & 512 & $5000<$ & $5000<$ & 1000 & 1000 & 512 \\
\hline 9 & 256 & 64 & 64 & 256 & 128 & 64 & 64 & 64 & 2000 & 256 \\
\hline 10 & 1000 & $5000<$ & 256 & 512 & 2000 & $5000<$ & 1000 & 2000 & $5000<$ & 1000 \\
\hline 11 & 512 & 128 & 64 & 64 & 64 & 64 & 1000 & 256 & 1000 & 512 \\
\hline 12 & 1000 & 128 & 128 & 64 & 64 & 512 & 128 & 256 & $5000<$ & 256 \\
\hline 13 & 2000 & 512 & 256 & 128 & 128 & 64 & 256 & 1000 & 2000 & 1000 \\
\hline 14 & $5000<$ & 2000 & 1000 & $5000<$ & $5000<$ & 256 & 128 & 64 & 1000 & 2000 \\
\hline 15 & $5000<$ & 1000 & 256 & 256 & 256 & 256 & 512 & 512 & 2000 & 128 \\
\hline
\end{tabular}

Table 2: Growth inhibition Zone (mm)

$\begin{array}{ccccccccccc} & \begin{array}{c}\text { Lagenaria } \\ \text { vulgaris }\end{array} & \begin{array}{c}\text { Punica } \\ \text { granatum }\end{array} & \begin{array}{c}\text { Allium } \\ \text { ascalonicum }\end{array} & \begin{array}{c}\text { Persian } \\ \text { marjoram }\end{array} & \begin{array}{c}\text { Urtica } \\ \text { dioica }\end{array} & \begin{array}{c}\text { Cichorium } \\ \text { intybus }\end{array} & \begin{array}{c}\text { Rubia } \\ \text { tinctorum }\end{array} & \begin{array}{c}\text { Trigonella } \\ \text { foenum }\end{array} & \begin{array}{c}\text { Descurainia } \\ \text { sophia }\end{array} & \begin{array}{c}\text { Pistacia } \\ \text { vera }\end{array} \\ 2 & - & - & 29 & - & 8 & - & - & - & - & 15 \\ 2 & - & - & 30 & - & 8 & - & - & - & - & 8 \\ 3 & 8 & - & 27 & 11 & - & 9 & 12 & 8 & - & 10 \\ 4 & 8 & - & 30 & 9 & 8 & 10 & 10 & 12 & 8 & 9 \\ 5 & - & 8 & 25 & 13 & - & - & 9 & - & - & 10 \\ 6 & - & - & 11 & 15 & - & 12 & - & - & 8 & 9 \\ 7 & - & - & 27 & 11 & - & 8 & - & 8 & 8 & 11 \\ 8 & 8 & 8 & 22 & 10 & - & - & 8 & - & - & 13 \\ 9 & - & 13 & 20 & 10 & - & - & - & 10 & 10 & 12 \\ 10 & - & 12 & 20 & 20 & 10 & - & - & 10 & 8 & 10 \\ 11 & 9 & - & 10 & 12 & 8 & 11 & 9 & 12 & - & - \\ 12 & 10 & 9 & 28 & 15 & 13 & 9 & 16 & 8 & 9 & 15 \\ 13 & 13 & 8 & 29 & 13 & 12 & 11 & 16 & 15 & 12 & - \\ 14 & - & - & 12 & - & - & 10 & - & 12 & 8 & 8 \\ 15 & 8 & - & 22 & 12 & 8 & 12 & 12 & - & - & 11\end{array}$

Table 3: $\mathrm{MIC}_{50}$ and $\mathrm{MIC}_{90}$ values- microgram per milliliter $(\mu \mathrm{g} / \mathrm{ml})$ -

$\begin{array}{lcc} & \text { MIC }_{50} & \text { MIC } 90 \\ \text { Lagenaria vulgaris } & 1000 & 5000< \\ \text { Punica granatum } & 256 & 5000< \\ \text { Allium ascalonicum } & 128 & 512 \\ \text { Persian marjoram } & 256 & 1000 \\ \text { Urtica dioica } & 256 & 2000 \\ \text { Cichorium intybus } & 256 & 5000< \\ \text { Rubia tinctorum } & 256 & 1000 \\ \text { Trigonella foenum } & 512 & 2000 \\ \text { Descurainia sophia } & 1000 & 5000< \\ \text { Pistacia vera } & 512 & 2000\end{array}$

\section{Discussion And Conclusion}

$S$. epidermidis is a major pathogenic bacterium known as a cause of infections in urinary system, dermal infection, septicemia, and bone and joint infections. It is also known for its resistance to natural factors such as dryness, antibiotic, and antiseptic treatments, leading to variety of nosocomial infections [6,24]. The problem of treating the infections caused by this antibiotic-resistance bacterium has become so challenging that 
today can only be overcome by a few medicines, including one of the recently developed antibiotics, i.e. vancomycin which is still used to cure many infections caused by $S$. epidermidis [25,26].

With the development of resistance to vancomycin in enterococci and the transfer of resistant genes to S. epidermidis, we now experience the prevalence of vancomycin-resistant or intermediate-resistant strains[12,24]. Since vancomycin is one of the latest medicines developed for this purpose, it is crucially important to regularly search for medicines or anti-staphylococcus compounds. According to a report by CLSI, those strains of S. epidermidis whose growth can be inhibited by vancomycin at the concentrations 8 to $16 \mu \mathrm{g} / \mathrm{ml}$ are considered semi-resistant to vancomycin [20]. Strains that are sensitive to smaller concentrations are called sensitive strains while strains with MICs over $32 \mu \mathrm{g} / \mathrm{ml}$ are considered vancomycin-resistant strains. Antimicrobial resistance in CoNS is similar to that seen in S. aureus, although they generally are more resistant. Reduced vancomycin susceptibility is more frequent in S. haemolyticus and S. epidermidis than in S. aureus $[27,28]$.

A previous study on the inhibiting effects of 20 herbs on methicillin-resistant staphylococci reported an MIC of $200 \mu \mathrm{g} / \mathrm{ml}$ while the smallest $\mathrm{MIC}_{50}$ was found to be $128 \mu \mathrm{g} / \mathrm{l}$ [29]. A similar study explored the impacts of 19 Chinese medicinal herbs on methicillin-resistant staphylococci and reported an MIC ranging between 1.1 and $3.07 \mu \mathrm{g} / \mathrm{l}$ [30]. Yet another study in the same vein measured the antibacterial properties of isoflavonoids isolated from Erythrinavariegata against methicillin-resistant staphylococci. Compounds like erycristagallin and orientanol with the MIC3 $\cdot 13-6 \cdot 25 \mu \mathrm{g} / \mathrm{ml}$ were found to be the most effective one in terms of antimicrobial properties [31].

Another study reported an MIC of $12 \mu \mathrm{g} / \mathrm{ml}$ for alpha-mangostin from Garciniamangostana $L$. in treating vancomycin-resistant enterococci and methicillin-resistant $S$. epidermidis [32].

Sakagami et al. found that MIC of Calozeyloxanthone isolated from Calophyllummooni against vancomycin-resistant Enterococci (VRE) and vancomycin-sensitive Enterococci (VSE) with MIC values of $6.25 \mu \mathrm{g} / \mathrm{ml}$ and $12.5 \mu \mathrm{g} / \mathrm{ml}$, respectively [33].

A study by Fisgin et al. found that Ankaferd Blood Stopper has growth inhibitory effect on clinical isolates Gram negative and positive bacteria, and Methicillin-resistant coagulase-negative staphylococci, from a hospital in Turkey. Ankaferd Blood Stopper is a mixture of 5 medicinal plants, Thymus vulgaris, Glycyrrhiza glabra, Vitis vinifera, Alpinia officinarum and Urtica dioica, which has been used in managing hemorrhage and bleedings in Turkey [34].

Many of Allium family member vegetables are known for their antimicrobial characteristics and also many researches have been done on Allium vegetables. N. Benkeblia et al. examined the Antimicrobial activity essential oil extracts of three types of onions and garlic against bacteria and fungi and according to this study garlic showed highest inhibition and green onion the lowest [35].

Given the prevalence of vancomycin-resistant $S$. epidermidis in many countries, the findings of this study, particularly those related to the effects of Allium ascalonicum extract on all strains of vancomycinresistant S. epidermidis, can be quite important. The findings in disk diffusion method suggest limited impacts of antimicrobial agents on the strains studied here. However, further studies are required into the clinical application of these herbs. Successful and standardized results may indicate usefulness of these herbs as supplement medicines in treating infections caused by S. epidermidis.

\section{Acknowledgements}

The authors would like to thank the Agricultural Research Center of the East Azerbaijan province for their support in carrying out this work.

\section{References}

[1] Hamory BH, Parisi JT. (1987): Staphylococcus epidermidis: A significant nosocomial pathogen. American journal of infection control, 15(2), 59-74.

[2] O'GARA JP, Humphreys H. (2001): Staphylococcus epidermidis biofilms: importance and implications. Journal of medical microbiology, 50(7), 582-587.

[3] Gurskis V, Kevalas R, Keriene V, Vaitkaitiene E, Miciuleviciene J, Dagys A, et al. (2010): Economic evaluation of nosocomial infections in pediatric intensive care units in Lithuania. Medicina (Kaunas), 46(11), 781-789.

[4] Zhao X, Wang LH, Zhang JL, Ma WH, Wang GZ. (2008): Economic loss of nosocomial infections in patients with cerebral hemorrhage or cerebral infarction. Zhongguo Yi Хие Ke Хие Yuan Хие Bao, 30(5), 543-545.

[5] Losos J, Trotman M. (1984): Estimated economic burden of nosocomial infection. Can J Public Health, 75(3), 248-250.

[6] Jaglic Z, Michu E, Holasova M, Vlkova H, Babak V, Kolar M, et al. (2010): Epidemiology and characterization of Staphylococcus epidermidis isolates from humans, raw bovine milk and a dairy plant. Epidemiol Infect, 138(5), 772-782.

[7] Vuong C, Otto M. (2002): Staphylococcus epidermidis infections. Microbes and infection, 4(4), 481-489.

[8] Ishak M, Gröschel D, Mandell G, Wenzel R. (1985): Association of slime with pathogenicity of coagulase-negative staphylococci causing nosocomial septicemia. Journal of clinical microbiology, 22(6), 1025-1029.

[9] Schwalbe RS, Stapleton JT, Gilligan PH. (1987): Emergence of vancomycin resistance in coagulase-negative staphylococci. New England Journal of Medicine, 316(15), 927-931.

[10] Dunne WM, Jr., Qureshi H, Pervez H, Nafziger DA. (2001): Staphylococcus epidermidis with intermediate resistance to vancomycin: elusive phenotype or laboratory artifact? Clin Infect Dis, 33(1), 135-137. 
[11] Gazzola S, Cocconcelli PS. (2008): Vancomycin heteroresistance and biofilm formation in Staphylococcus epidermidis from food. Microbiology, 154(Pt 10), 3224-3231.

[12] Garrett DO, Jochimsen E, Murfitt K, Hill B, McAllister S, Nelson P, et al. (1999): The emergence of decreased susceptibility to vancomycin in Staphylococcus epidermidis. Infect Control Hosp Epidemiol, 20(3), 167-170.

[13] Rajendran R, Radhai R, Kotresh TM, Csiszar E. (2013): Development of antimicrobial cotton fabrics using herb loaded nanoparticles. Carbohydr Polym, 91(2), 613-617.

[14] Radulovic NS, Blagojevic PD, Stojanovic-Radic ZZ, Stojanovic NM. (2012): Antimicrobial Plant Metabolites: Structural Diversity and Mechanism of Action. Curr Med Chem.

[15] Singh D, Kumar TR, Gupt VK, Chaturvedi P. (2012): Antimicrobial activity of some promising plant oils, molecules and formulations. Indian J Exp Biol, 50(10), 714-717.

[16] Arif T, Bhosale JD, Kumar N, Mandal TK, Bendre RS, Lavekar GS, et al. (2009): Natural products--antifungal agents derived from plants. J Asian Nat Prod Res, 11(7), 621-638.

[17] Kovac-Besovic EE, Duric K, Basic F, Subasic D, Imamovic J. (2003): Potential antimicrobial effects of pharmacognostic drugs. Bosn J Basic Med Sci, 3(4), 16-22.

[18] Kemertelidze É, Syrov V, Alaniya M, Kavtaradze NS, Khushbaktova Z. (2008): Chemical composition and pharmacological activity of the leaves of Pueraria hirsuta L. grown in Georgia. Pharmaceutical Chemistry Journal, 42(6), 340-343.

[19] Lalitha M. (2005): Manual on antimicrobial susceptibility testing. Indian Association of Medical Microbiologists, http://www.ijmm.org/documents/Antimicrobial.doc.

[20] Edition ASS. (2006): CLSI Document M7-A7. Clinical and Laboratory Standards Institute. Wayne, PA.

[21] BAUER AW, PERRY DM, KIRBY WMM. (1959): Single-disk antibiotic-sensitivity testing of staphylococci: An analysis of technique and results. Archives of Internal Medicine, 104(2), 208.

[22] Holzer C, Precht M. (1992): Multiple comparison procedures for normally distributed ANOVA models in SAS, SPSS, BMDP, and MINITAB. Computational statistics \& data analysis, 13(3), 351-358.

[23] Argyrous G. (2011): Statistics for research: With a guide to SPSS: Sage Publications Limited.

[24] Juarez-Verdayes MA, Reyes-Lopez MA, Cancino-Diaz ME, Munoz-Salas S, Rodriguez-Martinez S, de la Serna FJ, et al. (2006): Isolation, vancomycin resistance and biofilm production of Staphylococcus epidermidis from patients with conjunctivitis, corneal ulcers, and endophthalmitis. Rev Latinoam Microbiol, 48(3-4), 238-246.

[25] Aybar Y, Ozaras R, Besirli K, Engin E, Karabulut E, Salihoglu T, et al. (2012): Efficacy of tigecycline and vancomycin in experimental catheter-related Staphylococcus epidermidis infection: microbiological and electron microscopic analysis of biofilm. Int J Antimicrob Agents, 39(4), 338-342.

[26] Olson ME, Slater SR, Rupp ME, Fey PD. (2010): Rifampicin enhances activity of daptomycin and vancomycin against both a polysaccharide intercellular adhesin (PIA)-dependent and -independent Staphylococcus epidermidis biofilm. J Antimicrob Chemother, 65(10), 2164-2171.

[27] Cavalieri SJ. (2009): Manual of Antimicrobial Susceptibility Testing: American Society for Microbiology.

[28] Coyle MB. (2005): Manual of Antimicrobial Susceptibility Testing: American Society for Microbiology.

[29] Dadgar T, Asmar M, Saifi A, Mazandarani M, Bayat H, Moradi A, et al. (2006): Antibacterial Activity of Certain Iranian Medicinal Plants Against Methicillin-Resistant and Sensitive Staphylococcus aureus. Asian Journal of Plant Sciences, 5, 861-866.

[30] Zuo G, Wang G, Zhao Y, Xu G, Hao X, Han J, et al. (2008): Screening of Chinese medicinal plants for inhibition against clinical isolates of methicillin-resistant Staphylococcus aureus (MRSA). Journal of Ethnopharmacology, 120(2), 287-290.

[31] Tanaka H, Sato M, Fujiwara S, Hirata M, Etoh H, Takeuchi H. (2002): Antibacterial activity of isoflavonoids isolated from Ery thrina variegata against methicillin resistant Staphylococcus aureus. Letters in applied microbiology, 35(6), 494-498.

[32] Sakagami Y, Iinuma M, Piyasena K, Dharmaratne H. (2005): Antibacterial activity of $\alpha$-mangostin against vancomycin resistant Enterococci(VRE) and synergism with antibiotics. Phytomedicine, 12(3), 203-208.

[33] Sakagami Y, Kajimura K, Wijesinghe W, Dharmaratne H. (2002): Antibacterial activity of Calozeyloxanthone isolated from Calophyllum species against Vancomycin-resistant Enterococci (VRE) and synergism with antibiotics. Planta medica, 68(06), 541543 .

[34] Tasdelen Fisgin N, Tanriverdi Cayci Y, Coban AY, Ozatli D, Tanyel E, Durupinar B, et al. (2009): Antimicrobial activity of plant extract Ankaferd Blood Stopper sup®. Fitoterapia, 80(1), 48-50.

[35] Benkeblia N. (2004): Antimicrobial activity of essential oil extracts of various onions ( Allium cepa) and garlic ( Allium sativum). LWT-Food Science and Technology, 37(2), 263-268. 